The 16th Economic International Conference

New Challenges and Opportunities for the Economy 4.0, May 7-8th, 2020, Suceava, Romania

\title{
Organizational Trust - Result of Formal and Informal Relationships Development in Business Organizations
}

\author{
Simona BUTA \\ https://doi.org/10.18662/lumproc/ncoe4.0.2020/20
}

How to cite: Buta, S. (2020). Organizational Trust - Result of Formal and Informal Relationships Development in Business Organizations. In C. Nastase (vol. ed.), Lumen Proceedings: Vol. 13. 16th Economic International Conference NCOE 4.02020 (pp. 226-236). Iasi, Romania: LUMEN Publishing House.

https://doi.org/10.18662/lumproc/ncoe4.0.2020/20 


\title{
Organizational Trust - Result of Formal and Informal Relationships Development in Business Organizations
}

\author{
Simona BUTA ${ }^{1}$
}

\begin{abstract}
There are studies and applications that have argued that trust, as a phenomenon, exceeds the interpersonal limit, it leaving its mark both at the organizational level and at the socio-economic level. Thus, trust becomes an important aspect for leading organizations and not only.

The present research aims to analyse the relationship between organizational trust and all formal and informal networks / relationships from business organizations in North-eastern Romania. The research aimed to identify whether there is a strong link between the promotion of formal relationships by management and a high level of trust and the development of informal relationships. For this research we used a descriptive, empirical-analytical methodology.

The data obtained from the interpretation of the questionnaire, at the level of the companies included in our sample showed that there is a strong link between formal relationships and networks (such as internal relationships to a company and which are given by organization chart, internal rules and various regulations) and relations and informal networks (in which case we are talking about informal relationships that double the internal organization chart of a company) and the degree of trust. The strong connection is demonstrated by the coefficients obtained (e (128) = 0.430 - demonstrating the high correlation between formal and informal relations, respectively $\varrho$ $(128)=0.407$ - demonstrating the high correlation between formal relations and the degree of trust). This means that a more precise delimitation of formal working groups stimulates the creation of a climate of trust between compartments / departments / groups. If the organizational climate in the company allows the development of personal relationships, there is a certain level of trust between employees. Moreover, we have identified the fact that at the level of the companies included in our sample there is a greater or lesser concern of the decision makers from these companies in the development and operation of informal networks / groups; we must mention that this concern is different by activity sectors / companies.
\end{abstract}

Keywords: trust; organizational trust; formal relationships/networks; informal relationships.

1 “Stefan cel Mare” University of Suceava, Romania, simonab@,usm.ro 


\section{Introduction}

There are studies and applications that have argued that trust, as a phenomenon, exceeds the interpersonal limit, it leaving its mark both at the organizational level and at the socio-economic level. Thus, trust becomes an important aspect for leading organizations and not only.

Moreover, individual, organizational and interorganizational trusts are interconditioned. Individual trust is considered as a mechanism for promoting organizational trust. Individual and organizational trust influences each other when managers learn what kinds of behaviours are to be rewarded or penalized in their organization [17].

Studies has shown that between organizational, interorganizational and interpersonal trust there is a dynamic, the development or deterioration of one level has an impact on other levels [18].

\section{Review of Literature}

Trust is approached from various angles, each raising issues of definition and operationalization; however, we were trying to capture a number of basic elements that may be relevant in understanding the concept of organizational trust.

\subsection{Hypostases and characteristics of organizational trust in foreign literature}

The foreign literature is quite generous and varied in terms of the concept of organizational trust. In Table 1 we selectively present these ideas around which organizational trust is defined.

Table 1 Hypostases and characteristics attributed to organizational trust

\begin{tabular}{|l|l|}
\hline \multicolumn{1}{|c|}{ Authors } & $\begin{array}{c}\text { Basic elements in defining organizational } \\
\text { trust from a psychological, sociological and } \\
\text { economic perspective }\end{array}$ \\
\hline $\begin{array}{l}\text { Gulbert and McDonough } \\
\text { (1986) [8] }\end{array}$ & $\begin{array}{l}\text { Trust is manifested when individuals are able to } \\
\text { appreciate the actions of others and when there } \\
\text { is mutual respect, especially when the needs of } \\
\text { the parties involved do not consist in the } \\
\text { struggle/fight for control of the action. }\end{array}$ \\
\hline $\begin{array}{l}\text { Carnevale and Weschler } \\
\text { (1992) }\end{array}$ & $\begin{array}{l}\text { Trust is the expectation of the other to behave } \\
\text { ethically, correctly, non-threateningly and that is } \\
\text { concerned with the rights of others. }\end{array}$ \\
\hline
\end{tabular}




\begin{tabular}{|l|l|}
\hline McAllister (1995) & $\begin{array}{l}\text { Trust is the faith and desire to act on the words, } \\
\text { actions, and decisions of others. It can be } \\
\text { described according to "the extent" to which one } \\
\text { person believes and wants to act on the words, } \\
\text { actions and decisions of another. }\end{array}$ \\
\hline Zaheereta1 (1996) & $\begin{array}{l}\text { Trust refers to the perspectives that individuals } \\
\text { have on networks of relationships and } \\
\text { organizational behaviours. }\end{array}$ \\
\hline $\begin{array}{l}\text { [14] } \\
\text { [7] }\end{array}$ & $\begin{array}{l}\text { Trust refers to the psychological state that } \\
\text { encompasses the intention to accept vulnerability } \\
\text { based on positive expectations about other } \\
\text { people's behavioural intentions. }\end{array}$ \\
\hline $\begin{array}{l}\text { Kramer and Tyler (1996) } \\
\text { [11] }\end{array}$ & $\begin{array}{l}\text { Trust is related to social networks, networks } \\
\text { in which negotiation and trust take place and its } \\
\text { members accept the relations of domination and } \\
\text { power. }\end{array}$ \\
$\begin{array}{l}\text { Trust involves an individual or group relying on } \\
\text { each other in terms of understanding and risk. } \\
\text { One party is "obliged" to rely on the other to } \\
\text { achieve a goal. The decision to enter into a } \\
\text { supportive relationship is predicted primarily by } \\
\text { the calculation of risk. In other words, each party } \\
\text { must have a stake in the end result. }\end{array}$ \\
\hline $\begin{array}{l}\text { Shockley-Zalabak, Ellis, and } \\
\text { Winograd (2000) [16] }\end{array}$ & $\begin{array}{l}\text { Organizational trust is a construct described by a } \\
\text { positive expectation that individuals have about } \\
\text { the intentions and behaviours of multiple } \\
\text { members of the organization based on } \\
\text { organizational roles, relationships, experience } \\
\text { and interdependencies. }\end{array}$ \\
\hline and Kreitner (2003) & $\begin{array}{l}\text { Trust is mutual faith in the intentions and } \\
\text { behaviour of others. }\end{array}$ \\
\hline
\end{tabular}

Source: adapted by Avram, E and Pamela Shockley-Zalabak, Trust: The Bedrock of Individual and Organizational Excellence, Publishing House: Universitară, București, 2008, p. 66 [3]

If we take into account the various hypostases attributed to organizational trust by theorists over time we deduce the multidisciplinary nature of the trust construct, which is explained by various sciences in various ways and the consensual nature of different definitions, despite significant differences between authors. It can be considered as an anticipation of behaviour, as a natural effect of the calculation of probabilities or as an assumption of a risk. 


\subsection{Organizational trust in Romanian literature}

In the case of Romanian authors [9],[13], [4], [19], [6], [1], the basic idea that emerges from their studies is that organizational trust is a variable with positive and negative effects in public and private organizations investigated.

For example, Avram (2007) [2] identified that in neurosurgery services all dimensions of trust are positively correlated with: job satisfaction, self-esteem at work, perceived formal power, receptivity / openness of superiors, interactional justice, peer support, guidance in work, development opportunities. The dimensions of trust are negatively correlated with: stress related to work materials, physical working conditions, role ambiguities, physical exhaustion and negative emotions at work.

\section{The Research Problem}

The present research aims to analyse the relationship between organizational trust and all formal and informal networks / relationships in business organizations in North-eastern Romania.

The research aimed to identify whether there is a strong link between the promotion of formal relationships by management and a high level of trust and the development of informal relationships [15].

We started from the premise that when the structural components (eg organizational framework, rules, mechanisms or practices) are relatively stable over time, then both the perception of trust and justice are positive.

\section{Instrument Testing/Method}

In essence, our research was based on the use of a questionnaire adapted to the general objective of the study and the working principles established by the literature.

The questionnaire was administered to a number of 13 companies from the North-East area of Romania. A first step was to contact some companies in the forest industry sector in North-East Romania.

Initially, the developed tool (the questionnaire) was sent to 6 companies in the forest industry sector, with a very low response rate $(4 \%)$. The second option we used was to set up a sample of four representative companies operating in the field of construction, seven companies operating in the field of insurance and two companies operating in the field of IT.

In summary, we mention the following aspects regarding the distribution of the respondents from the sample of companies constituted: 
- a number of 130 valid questionnaires were obtained (61\% nonmanagers, $14 \%$ middle management, $7 \%$ senior management, $10 \%$ parttime, etc.);

- the distribution of the respondents to the questionnaire shows: $1 \%$ doctoral studies, $61 \%$ have university studies, $19 \%$ postgraduate studies, $15 \%$ high school studies and the difference of about $4 \%$ studies up to high school level [5].

\section{Data Analysis and Results}

Correlation coefficients demonstrated a strong link between formal relationships and networks (such as those internal to a company and which are given by the organization chart, internal rules and various regulations) and informal relationships and networks (in which case we discusses about the informal relationships that come to double the internal organization chart of a company) and the degree of trust.

The strong link is demonstrated by the obtained coefficients ( $\varrho(128)$ $=0.430$ - demonstrating the high correlation between formal and informal relations, respectively $\varrho(128)=0.407-0.407$ - demonstrating the high correlation between formal relations and the degree of trust) [5].

This means that a more precise delimitation of formal working groups stimulates the creation of a climate of trust between compartments / departments / groups.

If the organizational climate in the company allows the development of personal relationships, there is a certain level of trust between employees.

In order to determine a prediction model for the manifestation of team spirit and the degree of trust according to variables: organizational chart and formal / informal groups, we used the calculation of the Pearson correlation coefficient $(\mathrm{r})$.

The Pearson correlation coefficient ( $r$ ) measures the degree of association between variables. This refers to the degree and meaning of concomitant variation of the values of one variable in relation to the other, according to a linear type model.

The table of results includes the correlation matrix of the analysed variables. It is redundant because it has the same correlations twice, once above the diagonal, once below the diagonal. The correlations of the variables with themselves are perfectly positive $(r=1)$ and are, of course, of no interest.

The matrix presented below contains the data obtained. 
Table 3.1. Calculation of the Pearson correlation coefficient

\begin{tabular}{|c|c|c|c|}
\hline \multirow{3}{*}{ Independent variakle } & & DEP1 & DEP2 \\
\hline & & Team Spirit & Trust \\
\hline & & & \\
\hline INDEP1 & $\begin{array}{l}\text { Pearson } \\
\text { Correlation }\end{array}$ & $.406(* *)$ & $.250(* *)$ \\
\hline \multirow{2}{*}{$\begin{array}{l}\text { The type of } \\
\text { organization } \\
\text { chart and its } \\
\text { operation }\end{array}$} & Sig. (2-tailed) & .000 & .007 \\
\hline & $\mathrm{N}$ & 130 & 114 \\
\hline INDEP2 & $\begin{array}{l}\text { Pearson } \\
\text { Correlation }\end{array}$ & $.793(* *)$ & $.370(* *)$ \\
\hline \multirow{2}{*}{$\begin{array}{l}\text { Formal groups / } \\
\text { networks }\end{array}$} & Sig. (2-tailed) & .000 & .000 \\
\hline & $\mathrm{N}$ & 130 & 114 \\
\hline INDEP3 & $\begin{array}{l}\text { Pearson } \\
\text { Correlation }\end{array}$ & $.615(* *)$ & $.293(* *)$ \\
\hline \multirow{2}{*}{$\begin{array}{l}\text { Informal groups } \\
\text { / networks }\end{array}$} & Sig. (2-tailed) & .000 & .002 \\
\hline & $\mathrm{N}$ & 130 & 114 \\
\hline
\end{tabular}

** Correlation is significant at the 0.01 level (2-tailed).

Source: Own elaboration

From table no.3.1., we notice that there is a significant positive correlation between the type of organization chart and its functioning, formal groups / networks, informal groups / networks and team spirit, $r$ $(128)=0.406, \mathrm{r}(128)=0.793, \mathrm{r}(128)=0.406, \mathrm{p}<0.001$ (128 represents the degrees of freedom $\mathrm{df}=\mathrm{N}-2$, where $\mathrm{N}$ represents the number of subjects).

There wasn't identified a strong link between the type of organizational chart and its functioning groups / formal networks, groups / informal networks and trust.

The graph below shows that the relationship between DV (dependent variable) and each IV (independent variable) is linear, and inspecting the correlation coefficients in the Correlations table, we find that the correlations between each IV and DV are medium and high. 


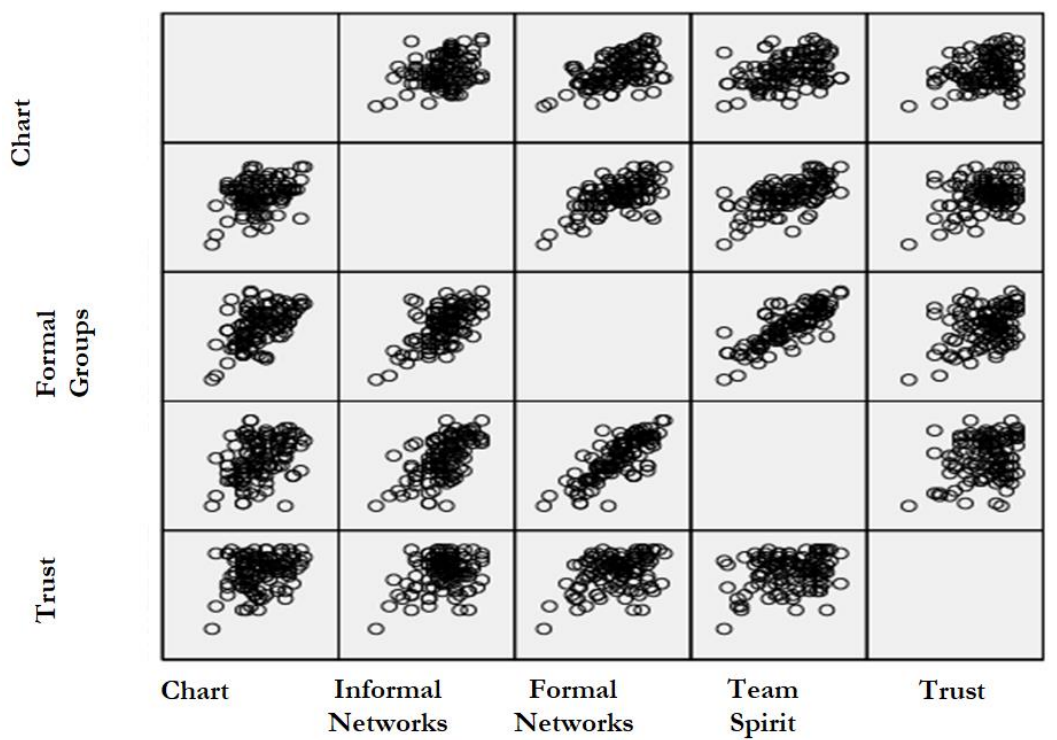

In order to determine a prediction model for the trust level according to the formal groups / networks, was used linear regression model type:

$$
\mathrm{Y}=\alpha+\beta \mathrm{X}, \text { where }
$$

- Y - represents the degree of trust;

$-\alpha$ has a constant value;

- Xrepresents the formal group variable.

Table no. 3.2 gives us the first information about the efficiency of the applied regression model.

Table 3.2. Model Summary

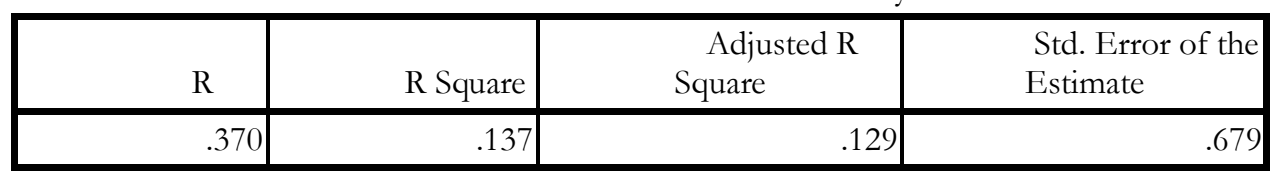

The independent variable is Formal Groups

As $\mathrm{R}=0.370$, it results that there is no strong correlation between the model variables. Determination coefficient R2 $=0.137$, which means that $13.7 \%$ of the variation of the dependent variable (degree of trust) can be explained by the variation of the independent variable (formal groups). We can say that the trust level is explained in a share of $13.7 \%$ by the variation of the independent variables. 
In our case, adjusted $\mathrm{R}^{2}=0.129$, the difference being minimal compared to $\mathrm{R}^{2}$. Therefore, we can say that the types of formal groups / networks that are formed within a company influence in a proportion of $12.9 \%$ the degree of trust.

In the following table, ANOVA, the $\mathrm{F}$ test checks if the regression line is significantly different from 0 , ie if the prediction we make is better than the one based on chance, hazard. As $F(1,112)=17,773$ is significant $(p<0.001)$ it results that it is very unlikely that our results will appear from a sampling error.

Table 3.3 ANOVA

\begin{tabular}{|l|r|r|r|r|r|}
\hline & Sum of Squares & df & Mean Square & F & Sig. \\
\hline Regression & 8.188 & 1 & 8.188 & 17.773 & .000 \\
Residual & 51.602 & 112 & .461 & & \\
Total & 59.791 & 113 & & & \\
\hline
\end{tabular}

The independent variable is Formal Groups

In table no. 3.4 are presented the non-standardized (B) and standardized (beta) regression coefficients as well as the results of the $t$ tests for each of these coefficients.

Table 3.4 Coefficients

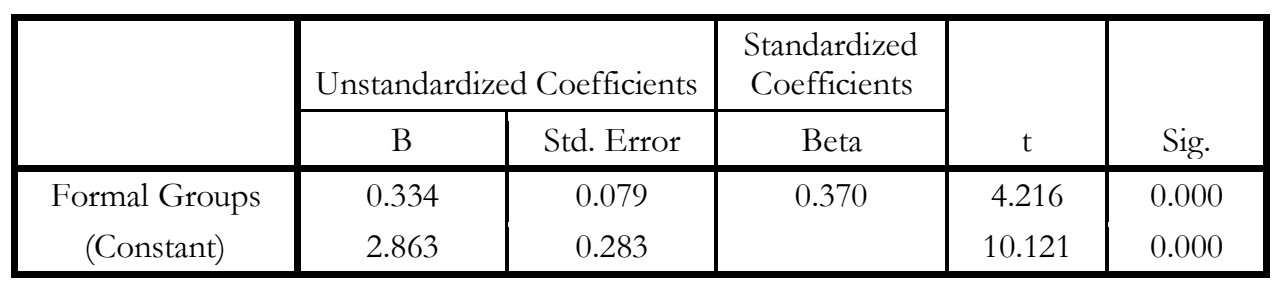

We can write the regression equation: $\mathrm{Y}=2.863+0.334 \mathrm{X}$ to predict the degree of trust based on the test score. Thus, we estimate that there is a weak link between the degree of trust and the types of formal groups / networks, but the need for a stable organizational framework over time will also reflect positively on organizational trust [5].

\section{Final Conclusion}

As the data obtained from the interpretation of the questionnaire show us that at the level of the companies included in our sample there is a 
greater or lesser preoccupation of the decision makers from these companies in the development and operation of informal networks / groups; we must mention that this concern is different by activity sectors / companies.

In general, the exploitation of informal relations between employees is achieved through formal mechanisms, working procedures, regulations, joint projects, courses, meetings. However, these formal mechanisms are doubled by other informal mechanisms: parties organized by the company, but also by employees, joint meetings created ad-hoc during breaks or at the end of the program.

If managers' view of stimulating and developing informal relationships is different, we cannot say the same about the climate of trust between employees. Respondents unanimously appreciated that there is a climate of trust in their companies and, moreover, a climate of trust can lead to an organizational culture oriented towards top performance.

Therefore, in the light of these findings and taking into account the empirical results, several directions of action for the management of companies in North-East Romania emerge. If we generalize the conclusions we have reached, we can formulate certain theoretical recommendations for Romanian companies, respectively:

To find other mechanisms, besides the formal mechanisms, through which to fructify the potential of the development of the informal relations that occur in time inside an organization and in its external relations with other entities;

$>$ To create informal work contexts in which employees make additional efforts, respectively circumstances aimed at consolidating the values accepted at group-department-company level;

$>$ To promote an open climate, in which members exchange information and knowledge, both through formal and informal procedures;

$>$ To design long-term strategies in various action plans that are not limited only to profit as a performance criterion;

To gradually develop civic responsibility and inter-group trust within the organization and on this basis in relation to outside groups. As, trust supports long-term commitment to the organization and becomes an important aspect for the performance of organizations. It reduces uncertainty, gains resources and solves problems. And last but not least, as Bridges (2004) points out when trust does not exist, progress is unlikely to happen. 


\section{References}

[1] Avram E, Shockley-Zalabak P. Trust: The Bedrock of Individual and Organizational Excellence. Bucureşti: Editura Universitară; 2008.

[2] Avram E. "Directions of management development neurosurgical departments, în Avram, E. (coord.). Psihologie organizational managerială - perspective aplicative. București: Editura Universitară; 2007.

[3] Avram E. "Teorii ale încrederii organizaționale", în Avram, E., (Ed.), Psychology in Modern Organizations. Bucureşti: Editura Universitară; 2008.

[4] Brate A. Diagnoza multidimensională a stresului ocupațional la manageri". Revista de psihologie organizatională; 2004; IV (3-4).

[5] Buta S. Capitalul uman, capitalul social şi studiul relaţiilor informale din organizațiile de afaceri. București: Editura Prouniversitaria; 2016.

[6] Ciurea AV, Ciubotaru VG, Avram E. Dezvoltarea managementului în organizațiile sănătății. Excelența în sens neurochirurgie. Bucureşti: Editura Universitară; 2007.

[7] Clegg SR., Hardy C. Studying Organization - Theory and Method. London: Sage Publications; 1999.

[8] Gulbert SA, McDonough JJ. The politics of trust and organizational empowerment. Public Administration Quarterly,10; 1986.

[9] Iliescu D. Inovația metodologică în studiul organizational. Folosirea modelelor mentale, Revista de psihologie organizational; 2004; IV (1-2).

[10] Kinicki A, Kreitner R. Organizational Behavior - key concepts, skills \& bestpractice. Irwin, Boston: McGraw Hill; 2003.

[11] Kramer RM, Tyler TR. Trust in Organizations: Frontiers of Theory and Research, Sage, Thousand Oaks; 1996.

[12] Mc Allister, DJ. Affect and cognition-based trust as foundations for interpersonal cooperation in organizations. Academy of Management. 1995; 38(1).

[13] Pavalache-Ilie M. Relația anxietate - stil detranzacțieinterpersonală în munca funcționarilor publici". Revista de psihologie organizațională, 2004, (3-4).

[14] Rousseau DM, Sitkin SB, Burt RS, Camerer C. Not so Different After All: A Cross-Discipline View of Trust". The Academy of Management Review. 998; 23:393-404.

[15] Schein EH. Process consultation: its role in organization development, Addison-Wesley Pub. Co.; 1969.

[16] Shockley-Zalabak P, Ellis K, Winograd G. Organizational trust: What it means, why it matters. Organizational Development, nr. 18; 2000. 
[17] Whitener, EM, Brodt SE, Krosgaard MA, Werner JM. Managers as initiators of trust: An exchange of relationship for understanding managerial trustworthy behavior", The Academy of Management Review; 1998, 23(3).

[18] Zaheer, AB, McEvily B, Perrone V. „Does trust matter? Exploring the effect of interorganizational and interpersonal trust on performance, Organizational Science; 1998, 9 (2).

[19] Zlate M, Avram E. Încrederea organizatională - câteva probleme teoretice, Revista de psihologie organizational; 2005, V(2-3). 